\title{
HEERMEENEUTICS,
}

SEMLANTICS

AND CONTEETT

(INHHALT) OF MUSTC

\section{THE THREE SIDES OF MUSICAL CONTENT}

\section{V.N. Kholopova}

Annotation. The object of research in this article is musical content, examined in light of one of the new Russian theories of musical content and in light of analysis of the musical practice itself under the angle of this theory. The examined theory reveals the presence in music of three categories of content, named here as emotion, depiction and symbolism. The examined practice covers the main historical periods of the Early Modern and Contemporary Era - the Baroque, Classical, Romantic and $20^{\text {th }}$ Century periods. The object of attention in them consists only of the so-called "serious» academic classical music — operas, symphonies, concertos, oratorios and chamber music — but not folk or popular songs. The methodology of research is connected with semiotics or, to be precise, with the triad of signs developed by Charles Peirce - the icon, index and symbol, - which are interpreted by the author of the article as emotion, depiction and symbol. The conclusions arrived at in the research are as follows: in each historical time period there exists a distinct, individual correlation of the three sides of musical content - in the Baroque period all three of them stand on an equally high level, in Classicism emotions prevail, whereas depiction and symbolism are of secondary importance, in Romanticism emotions reach an apogee, depiction is activated to a greater level in the second half of the $19^{\text {th }}$ century, whereas symbolism is of minor importance, while in the $20^{\text {th }}$ century symbolism takes a primary position, emotions are brought to their extreme stages, while depiction is of minor importance. The novelty of the research consists in laying out a sturdy semiotic foundation for the method of the "three sides (categories) of musical content» and in bringing out conclusions about the comparative correlation of the most important musical historical time periods according to their content.

Keywords: musical content, Baroque, Classicism, Romanticism, 20 $0^{\text {th }}$ century, icon, index, symbol, emotion, depiction.

The three sides of musical content are, respectively - emotion, depiction and symbolism. They form a trichotomy of musical semantics which serves as one of the principal foundations of the Theory of Musical Content. This specific trichotomy is directly connected to the world-renowned and widely recognized trichotomy of signs developed by Charles Peirce ${ }^{1}$ : the icon, the index, and the symbol. Musical emotion corresponds to the icon, musical depiction to the index, and musical symbolism to the symbol. This musical-semiotic trichotomy may be seen as a primary expression of the three fundamental sides of musical content which were present in the musical culture of the Early Modern Period and the

Charles Peirce 1839-1914: American philosopher, logician, mathematician, and scientist.
Contemporary Age - from the $17^{\text {th }}$ to the $20^{\text {th }}$ century, beginning with the establishment of the paradigm of the Baroque epoch.

These three sides of musical content are not equal to each other in their status. The first one of them - musical emotion - is always indispensable in music. The second and third - depiction and symbolism - are not necessarily indispensable elements: they may or may not be present in musical compositions. Nonetheless, the art of music occasionally diverges away from the second and third categories, only to come back to incorporating them, discovering in them vivifying «nourishment» for its expressivity. The relationship between these categories of musical art turns out to be remarkably uneven in different styles of European (and world) academic music. In other words, this theoretical 
approach forms an effective method for characterizing the concept of music of any musical style or any musical-historic paradigm.

Basing ourselves on the three sides of musical content, we shall form a comparison between the major eras of music history, from the $17^{\text {th }}$ to the $20^{\text {th }}$ century: the Baroque period, Classicism, Romanticism, and the Twentieth Century. In each of these four periods one may find a different musical paradigm.

In the music of the Baroque era (from the early $17^{\text {th }}$ to the middle of the $18^{\text {th }}$ centuries) it is surprising how all the three sides of its content exist on the highest levels. This is the primary characteristic feature of its paradigm.

Musical emotion as a vivid and profound experience became an epochal achievement of this style. The main pioneer of this trend was Monteverdi with his theory and practice (called «the Second Practice») of the «agitated style» or «stile concitato.» This was also enhanced by the Theory of Single Affect, according to which a single affect encompassing an entire musical movement with a complete form must last for a lengthy period of time without changing into an opposite affect in order to produce a strong emotional impression. This view had existed for a long time, up until the time of Glinka, who wrote the following: «lt (a chorus singing in a dismal mood - V. Kh.) must continue for a sufficient period of time so that the sad impression is left in the hearts of the listeners»'. At a later date Rimsky-Korsakov remarked about «the ability of $17^{\text {th }}$ century musicians to sustain feeling for lengthy durations». In the Baroque era a new approach to text in music emerged, differing from that of the Renaissance period: the music did not necessarily reflect every single expressive word (as in the madrigal), but instead one key word was singled out toward the single affect of an entire musical movement and its respective form.

According to Johann Gottfried Walther ${ }^{2}$, "the word «affect» means the experiencing of emotion». The Baroque period saw the emergence of new types of classification and codification of musical affects. Athanasius Kircher ${ }^{3}$ and, subsequently, Walther established eight well-known musical affects to which a few others were added in the musical practice «moderation,» «joke» (as in Monteverdi's «scherzi musicali»), etc. In his treatise «Musical Grammar», Nikolai

Glinka, Mikhail. Polnoye sobraniye sochineniy. Literaturnye proizvedeniya i perepiska [Complete Works. Literary Works and Letters]. Vol. 1. Moscow, 1973, p.30.

Johann Gottfried Walther 1648-1748: German composer, theorist, organist, and lexicographer of the Baroque era. He was a cousin of J.S. Bach and the author of «Musicalisches Lexicon», Leipzig,1732.

Athanasius Kircher 1602-1680: 17 $7^{\text {th }}$-century German Jesuit scholar, published works within medicine, oriental studies, and geology.
Diletsky ${ }^{4}$ identified three types of music: happy, sad, and mixed. The following typology of affects was formed in Italian Opera: heroic, angry, lamenting, bravura, buffoonish, etc. These affects were linked to certain elements of musical language: modality, intervals, time signatures, duration and rhetorical musical figures.

The affects of the Baroque reached its apogee in the works of J.S. Bach. Let us compare such affects as, for example, "sorrow», «love», and "suffering» ${ }^{5}$, as found in his music. According to Kircher, «sorrow» is defined as "complaint», "sadness», and "grief». According to Bach, sorrow can be defined as moderate suffering. In musical compositions this is featured in the use of minor modes, infrequent chromaticism, dissonances, slow tempo, syncopation, rhythmical regularity and rhetorical musical figures such as "suspiratio,» «catabasis,» «circulatio,» «ellipsis,» etc. Examples of this include: the C-sharp minor Prelude from Book 1 and the F-minor prelude from Book 2 of the Well-Tempered Clavier. "Love» (i.e. the Love for God) is defined as «moderate sorrow» and is connected with the words «Herz» and «Liebe», which it is possible to express in music both by major and minor tonalities, along with fluid melodic motion, containing coloratura, syncopations, moderate dissonances, and use of the figures "suspiratio» and "catabasis.» A perfect example of this is the aria for soprano «Komm in mein Herzenshaus», from the cantata «Ein feste Burg». Here "suffering" forms a powerful affect connected to the text about the sufferings of Christ on the cross, human repentance and death. Here either slow or fast tempi are possible, as well as accumulation of chromaticism, the sharpest types of dissonances, suspensions, syncopations, along with the figures «patophoia,» «parrhesia,» «passus,» «duriusculus,» «saltus duriusculus,» «ellpsis,» «suspiratio,» and «exclamatio.» Characteristic examples include the Fugues in F-minor, F-sharp minor, and B-minor from Book 1 of the Well-Tempered Clavier.

If these aforementioned affects are compared to their direct opposites - courage, joy, etc., - we shall obtain a sufficiently contrasting set of means. Courage is embodied in the words about struggling with an enemy and the will toward victory and presumes a musical language with a moderate tempo, harmonic and melodic consonance, diatonic harmonies, homophonic texture, use of repeated arpeggios and coloratura. In this connection we can

Nikolai Diletsky c.1630-after 1680; Ukrainian-Russian composer and theorist.

They are examined with special attention in G.V. Leonova's work «J.S. Bach's Sacred Cantatas in Light of the Baroque Theories of Affect.» Diploma thesis (A. Yu. Kudryashov, research advisor. Moscow State Conservatory, 1995). 
cite the examples of the aria-duo «Mit unsrer Macht ist nichts getan» («With our Might is Naught Done») from J.S. Bach's cantata «Ein feste Burg» and the D-major Prelude from Book 2 of the Well-Tempered Clavier. The affect of Joy is brought in connection to the events of the birth of Christ (Christmas), as well as vocal glorification of the power of God and the Church, with the use of musical language containing major tonalities, infrequent amounts of dissonance, use of triads, intervals of thirds, fourths, fifths, octaves, fast tempi, lack of syncopations, triple meter and use of trumpets, trombones, and horns in the orchestra. Examples of this could be brought in the first and final movements of J.S. Bach's «Magnificat» in D-major. In the history of Russian music, exceptionally vivid affects of joy may be found in the early $18^{\text {th }}$ century Baroque contrapuntal vocal concerti: «The Heavens Rejoice» (by an anonymous composer), and «The Golden Trumpet» by Vasiliy Titov (ca. 1650-1715).

In the dynamic profile of Baroque musical compositions where the affect embodies a continuous process, climaxes are not characteristically present especially climactic points - and there are no «quiet climaxes». Instead, the development of the music is characterized by dynamic plateaus, zones and «blocks of sound.»

The pictorial side of musical content (i.e. depiction) in Baroque music stems from many important sources: the continuation of many of the artistic tendencies from the Renaissance (interest in nature and the individual's surrounding world), the birth of the genre of opera, with its inherent visualization of events, as well as the development of Protestant hermeneutics (in German music). In Italy, ideas from the Renaissance were continued by various composers, especially Vivaldi, with his programmatic cycle of violin concertos known as «The Four Seasons». In France the musical development formed an arch thrown from the $16^{\text {th }}$ century chanson to harpsichord pieces by Rameau, such as "Le Rappel des Oiseaux» and "La Poule» ${ }^{1}$. Opera and ballet stood at the core of Rameau's conception of genre in his harpsichord pieces, «Les Cyclopes,» «Les Sauvages,» and «Les Niais de Sologne.» The composer wrote about his piece "Les Tourbillons» that his intention was to depict «the swirling of dust evoked by strong winds». Couperin created an entire system out of his programmatic titles. Among his pieces for harpsichord, numbered in the hundreds, entire blocks are devoted to images of birds («Le Rossignol en Amour», "Les fauvetes Plaintives», «Le Coucou»), to plants and flowers («Les Guirlandes», «Les Pavots», «Les Vergers Fleuris»), to seas and rivers («Les Ondes», «Les gondoles de Délos»),

As mentioned by Vera Bryantseva. to military activity («Fanfares pour les rois de France»), to everyday life («le réveil-matin») and to people's characters («Les tricoteuses», «Les Vieux Seigneurs»). Couperin's musical portraits have prototypes in various literary works, such as «Les Caractères» by Jean de La Bruyere and «Les Visionnaires» by Jean Desmarets². The exemplary Baroque genre permeated with depiction by means of rhetorical musical figures was the Oratorio. Examples include vocal numbers from Handel's «Messiah» (N.4: «I will shake the Heavens and the Earth»), «Israel in Egypt» (N.5: «The Land Brought Forth Frogs,» N.6: «And There Came all Manner of Flies» and N.20: «The Surging Waters Stood Firm like a Wall») ${ }^{3}$. In J.S. Bach's music the immensely developed pictorial qualities were not only the expression of the humanistic aspirations present since the advent of the Early Modern Period, but also the manifestation of Protestant hermeneutics. Several dozens of examples are given in Albert Schweitzer's book about Bach: «Durch Adams Fall ist ganz verderbt» («Through Adam's Fall, Mankind Fell Too»), «Verhör und Geißelung» («The Interrogation and Flagellation of Christ»), «Erstanden ist der heilige Christ» («Christ is Risen»), «Der zufriedengestelle» («the Play of the Unchained Winds»), "Christ unser Herr zum Jordan kam» ("Christ our Lord Came to the Jordan,» the latter depicting the movement of waves along the Jordan River), "Siehe, ich will viel Fischer aussenden» («Behold, I will Send out Many Fishermen,» depicting lake Gennesaret), «Preise dein Glücke, gesegnetes Sachsen» («Praise your Good Fortune, Blessed Saxony;» this movement uses the word "Ostsee,» meaning the Eastern or Baltic Sea), «lch bin in mir vergnügt» («I am Content within Myself,» where the word «weltmeer» appears, meaning «the world of seas»), "Herr Gott, nun schleuß den Himmel auf» («Lord God, now Unlock Heaven,» depicting wavering, uncertain steps), "Heut» triumphieret Gottes Sohn» («This day our Lord Triumphant Rose,» depicting haughty steps), «Wer weiß, wie nahe mir mein Ende?» («Who Knows how Near is my End?,» depicting strokes of the pendulum), "Unser Mund sei voll Lachens» («Our Mouth was Filled with Laughter,» depicting laughter), «Höllische Schlange! Wird dir nicht bange?» («Hellish Serpent! Are Thou not Afraid?,» depicting the movement of snakes), "Auf meinen flügeln sollst du schwebenrising» ("On my Wings you Shall Soar,» depicting rising and flight in the air), «Wenn alles bricht wenn alles fall» («When all Things Break, when all Things Fall,» depicting the collapse and destruction of everything), «lch werde den Hirten schlagen,

More information on this can be found in Yakov Milstein's essay on Couperin published in the Russian edition of «L'Art de Toucher le Clavecin» by Francois Couperin (Moscow, 1973).

As noted by Tamara Livanova. 
und die Schafe werden sich zerstreuen» («l will Smite the Shepherds, and the Sheep shall be Scattered," depicting the dispersal of sheep), «In allen meinen Taten» («In All that I do / In All my Undertakings,» depicting images of lying down and rising up again), «Wir zittern und wanken» («We Tremble and Stagger,» depicting trembling), «Wohl dem, der sich auf seinen Gott» («Happy is the Man Who to his God,» depicting being wrapped in chains), etc.

Some instrumental pieces, which, obviously, do not convey any texts, may be interpreted as types of musical paintings through the pictorial aspects which are prominent in certain sections of them. For example, the emblem of the B-major prelude from the Well Tempered Clavier, Book 1 by Bach strongly correlates with specific verses from the Gospel of Luke (chapter 2, verses 8-15; meanwhile, verses 16-20 correlate with its subsequent fugue 1 ). Bach's music is permeated with visual images of flying angels playing on violins, of the Heavenly Host suddenly appearing from the sky, of choruses singing praise - «Gloria,» as well as of angels flying away toward heaven.

Many grounds exist for discussing the elaborate development in Baroque music of the category of Symbolism as one of the aspects of musical content in connection with the great figures from that time period - Monteverdi, Handel and particularly J. S. Bach. This category manifests itself in different ways - in the exegesis of the text, in the system of rhetorical musical figures and in the symbolism of numbers. Musical rhetorical figures abound in the operas and madrigals of Monteverdi (in such works as «La Coronazione di Poppea,» "Orfeo» and "Lamento D'Arianna»), in the oratorios of Handel (such as «lsrael in Egypt», "Samson»and «Messiah»), and in the cantatas, passions, choral arrangements, the Well Tempered Clavier, organ and chamber music of J.S. Bach. For example, in the first act of Monteverdi's opera «La Coronazione di Poppea,» numerous words related to affects are symbolized by such phrases as «on buoyant wings» or «in rapid flight,» symbolized by coloring effects, «unhappy/unfortunate one» depicted by a parrhesia (movement towards a diminished fifth), «destruction of the harvest,» symbolized by a catabasis, "diety/God,» illustrated by coloring effects, "farewell» and «the last instant of life,» depicted by a parrhesia (diminished fifth), "you are forgotten," also symbolized by a parrhesia (diminished fourth), «ill fate» and «suffering,» illustrated by dissonant suspensions in harmony, «lightning, lightning,» depicted by the use of tiratas, «O» - by an exclamatio, «And be in love with him»by a tmesis, etc.

See «The Symbolism of Bach's Music» by Vera Nosina, Tambov, 1993.
Rhetorical figures also serve the cause of musical depiction in the aforementioned examples from Handel's oratorios: "I will shake the Heavens and the Earth,» where they serve as coloring effects, «All they that see him laugh him to scorn,» «The Land Brought Forth Frogs» and «And There Came all Manner of Flies» — as mimeses, «The Surging Waters Stood Firm like a Wall» — as an antitheton. Rhetorical figures are inseparable from the illustrational inventions of Bach. For example, in the aforementioned B-major prelude from the Well-Tempered Clavier, Book 1 the figure of anabasis is used to depict the flight of angels in the skies, and this is done so intentionally that Carl Czerny saw it necessary in his edition of the WTC to fill in the sparse low register with and extra tonic note in the bass. Bach's figure-symbols speak out so prominently that in his purely instrumental works not infrequently concealed texts from the Holy Scripture could be found, sometimes quite unfolded in length. Such is particularly the case of the Passacaglia for organ in C-minor, in which the rhetorical musical figures suggest the events recounted in chapters 26,27 , and 28 of the Gospel of St. Matthew.

The symbolism of numbers was for the Baroque era a tribute to the long-standing tradition established by the directives of the Church. Correspondingly, it was most significant for music of religious nature, which, once again, turns our focus on J.S. Bach, although he was not a strong devotee of applying numerology to music. The numbers which he conceived of as indubitable symbols were: 3 - the emblem of the Divine Trinity, 7 - the days of Creation, 12 - the Apostles, and 33 - the age of Christ upon His crucifixion. Numbers which are derivative of the aforementioned also acquire symbolic connotations. Examples of these could be seen in the hermeneutics of the three themes in the Triple Fugue for organ, the three trumpets in the orchestra in «Magnificat» and the twelve variations in the «Crucifixus» chorus from the Mass in B-minor. The Passacaglia for organ in C-minor presents 21 (i.e. $3 \times 7$ ) statements of the main theme in the main section of the movement containing the variations, 12 statements of the theme in the final closing fugue and 33 statements of the theme altogether in the entire Passacaglia (33 presenting the sum of 12 and 21, which are mirror-images of each other). Numbers 14 and 41 are symbolic as presenting the sum of numbers which correspond to the letters « $B$ $A C H »$ and «J. S. BACH» in the German alphabet. An established practice has been to find 14 notes in the theme of the first Fugue in C-major from WTC Book 1. There are 14 notes in the first phrase and 41 notes in the entire melody of the chorale elaborated on by Bach, «Wenn wir in höchsten Nöten sein» (originally titled «Vor deinen Thron tret ich hiermit»). 
In summary, the paradigm of music established in the Baroque Era distinguished itself by its correlation between the highly charged waves of emotionality of musical sound and the multidimensional and symbolic luminescence of the semantic meaning surrounding it.

In the music of the Classical era (Haydn, Mozart and Beethoven, the Viennese Classicists) the relationship between the three sides of content was determined differently than in the Baroque period: emotion became all-encompassing, while depiction and symbolism withdrew to a secondary level. Since, from an aesthetic viewpoint, it is here that we witness the occurrence of the formation of «absolute music,» i.e. music of optimal expressivity, it follows that the main feature of the paradigm of Classical Music can be essentially characterized by the summarizing statement: "absolute music rests on the icon (i.e. emotional expression).»

Whereas in the Baroque era, including the time of Bach, it was likely to encounter a contemptuous attitude towards purely instrumental music - for example, the German writer Behr compared it to wallpaper - during the Classical period this type of music came to hold a primary position. Beethoven, who became the main bearer of this new concept absolutely self-sufficient, independent instrumental music, devoid of all programmatic features - felt himself to be incomparably freer, in his own account, in the symphonic genre than in opera, with all its scenery and text. The extent that this concept was unusual for that period of time may be evaluated in the reaction of $19^{\text {th }}$ century criticism to the particular composer who chose «Beethoven's path,»-Brahms, the creator of symphonies, concertos and chamber music, but not operas or oratorios.

In the domain of musical emotions, the principal concept was no longer the codified "affect», but living human «feeling» (das Gefühl or die Empfindung). Here it is possible to describe the Classical style as coming into contact with sentimentalism. Feeling was placed by the Classicists on such an elevated level, that it became possible for one contemporary scholar to formulate the following thesis: «In the Age of Reason, the central category of aesthetics became the category of Feeling ${ }^{1}$.

Very convincing is the statement made about feeling (still called «affect» at the time) by Johannes Mattheson (1681-1764), a prominent German music theorist from the first half of the $18^{\text {th }}$ century, whose work predetermined many of the trends of musical thought in the latter half of that century: «Without the required affect, music is not worth anything, means

Kirillina, Larisa. Klassichesky stil v muzyke XVIII — nachala XIX veka [The Classical Style in the Music of the $18^{\text {th }}$ and Early $19^{\text {th }}$ Century]. Moscow, 1996, p. 96. nothing, and produces no effect ${ }^{2} . »$ Examples of composers themselves writing about musical feeling can be found in the text program to Beethoven's Sixth, «Pastoral» Symphony. The composer uses the word «feeling» twice: in the first movement («Awakening of cheerful feelings (Empfindungen) upon arrival to the country») and in the fifth movement ("Shepherd's song: cheerful and thankful feelings (Gefühle) after the storm»).

Despite the importance of feeling among the Classicists, its typology in scholarly literature has not been realized to date. It is known that the musicians of that period made use of the term «temperament». In this way, Beethoven titled the introduction to the Finale of the string quartet opus 18, No.6 with the term «La Malinconia». According to the assertion of Schindler, the same "temperament» was what Beethoven had in mind in the second movement of the $7^{\text {th }}$ Piano Sonata, titled «Largo e Mesto.» As for the applicability of concepts of affects in the Baroque period, although their system did not exactly correspond to the "passions» and «feelings» in the music of the Classicists, the most important affects, such as those of «sadness» and «joy,» were continued in the given (Classical) period. Sadness tinged with tears was particularly inherent in music associated with liturgical genres, such as, for example, the «Lacrimosa» from Mozart's Requiem. In the «Arioso dolente» from Beethoven's 31st Piano Sonata, the affect of deep sadness came about, most likely, because at the time the composer had completed the composition of "Missa Solemnis,» which influenced the entire group of his late piano sonatas. A new achievement in the expression of the feeling of deep sadness became manifested in the heroic sorrow of Beethoven's funeral marches.

All in all, the emotional world of the Classicists differed significantly from that of the Baroque world. A fundamentally new aspect is disclosed by the predominance of joyful emotions, involving the domination of major tonalities. Other innovations included: the emergence of tempestuous emotions, unprecedented in the history of music, and, in contrast, the discovery of pre-Romantic states of meditation. Also new were the formations of emotionally contrasting themes and sections, as well as the development of climaxes with achievement of climactic points.

Emotions of joy in the works of the Viennese Classicists have especially many variants: energetic, brisk, heroic, pastoral, graceful and scherzo-like moods. The last of these deserves particular attention because more variants of the scherzo were

Cited from the book «Muzykal'naya estetika Zapadnoy Evropy XVII-XVIII vekov [The Musical Aesthetics of Western Europe of the $17^{\text {th }}$ and $18^{\text {th }}$ Centuries]. Moscow, 1971, p. 38. 
present in this era than in any other period of music history - in the scherzos, minuets, rondos, the many Finales of the symphonic cycles, as well as the first movements. The turbulent effervescence of emotion distinguished itself not only in the movements in minor tonalities, such as in the Finale of Beethoven's "Moonlight» sonata and the outer movements of the «Appassionata» (presenting the affect of rage on a new historical level), but also those in major tonalities - for example, the first movement of the "Waldstein» Sonata. The discovery of meditative states was exemplified by the first movements of the «Moonlight», $28^{\text {th }}$ and 31 st Sonatas. Emotionally contrasting themes and sections of musical forms in compositions were typified to the greatest degree in the musical compositions of Mozart and became even more profound in Beethoven's oeuvres (for instance, the "fanfares and sighs» of the principal themes of his sonatas, as well as the contrast between the themes of the primary and secondary theme groups in the expositions). Emotional contrast was further secured in simultaneity, as shown by certain secondary theme groups in sonata forms - in the first movement of Beethoven's Violin Concerto, the bright and lyrical new theme from the secondary theme group is presented together with the rhythmically articulate pulsations of the motif from the primary theme group.

A qualitatively new type of emotional process was manifested by the emotional modulation which occurred within a single movement - from the initial feeling to its opposite state. Typically, this occurred with the evolution of the secondary theme group - from the lyrical song-like character usually present in the secondary theme group towards the breakthrough into the direction of the active emotions inherent in the primary theme group, leading to their climax in the conclusive theme. A textbook example of this could be seen in the first movement of Beethoven's Fifth Symphony. Not only had such changes in emotion within a single movement been nonexistent prior to the Viennese Classicists, but they are difficult to locate in works created after their time, in the music of the Romantic Era and of the $20^{\text {th }}$ century. This type of actively procedural character of emotional development is connected with the emergence of dynamic points of climax, as opposed to the «dynamic terraces and plateaus» in the music of the Baroque Era.

The category of depiction in the sphere of musical content was regarded by the Viennese Classicists as the devaluation and simplification of musical art. The more concrete was the presence of subject matter and "sound-descriptiveness» in the music, the closer such a piece of music would be to being endowed with the dangerous feature of «poor taste», since it did not «describe feelings» but merely «depicted objects» Beethoven himself wrote the following in the manuscript of his Sixth Symphony about the imitation of birds' voices brought in by him in the second movement, the «Scene by the Brook» (the nightingale, the quail and the cuckoo): «More an expression of feeling than a painting.» Only in the genre of the Oratorio was depiction, following the traditions of the Baroque period, still quite in vogue - as, for example, in the oratorios of Haydn. In «The Creation,» particularly in the second movement, the composer (similarly to Handel) depicted in great detail the text of the work both by the vocal lines and by the orchestra. For example, the Aria (N. 24), set to the text the words «And radiates from the bright eyes the spirit of the Creator's image and touch,» includes ascending passages in the flutes. Upon the "Creator's breath», there are quivering staccato notes under legato slurs played by the violins. In the Trio (N. 27) there are ascending passages in the voices and woodwinds accompanying words «The Earth in all her beauty and might», but they end with an abrupt chord on a forceful sforzando. In «The Seasons» the following are depicted: wandering in the dark, the cock's crow, a shepherd's tune, a storm and tempest, a hunting scene, etc. Especially impressive is the «earthquake» in the Finale of «The Seven Last Words of Christ». Titles were also assigned to some of Haydn's symphonies: «The Hen», «The Bear», «The Clock», «The Surprise» - as humorous sobriquets (according to Larisa Kirillina). Depiction is essentially not characteristic to the symphonies, sonatas, and string quartets of Mozart. In Beethoven, even such significant subtexts as the Myth of Adonis in the Allegretto from the Seventh Symphony, or the creation of the world in the beginning of the Ninth Symphony are sharply overpowered by the sheer force of the ingenious emotional musical expression.

Symbolism in the music of Haydn, Mozart and Beethoven occupies the same subordinate position as depiction. Besides the "ad hoc symbolism," as presented in Haydn's «Farewell Symphony» (perhaps, the first example of «instrumental theatre» in music), in most cases symbolism is inherent in occasional programmatic titles, episodic rhetorical musical figures and verbal implications. Beethoven's $26^{\text {th }}$ Piano Sonata, «Das Lebewohl» («The Farewell») is an example of a programmatic title along with a symbolic subtext: the first principal motive is subscribed with the words «Lebe-wohl». An exceptional case of pure symbolism takes place in Beethoven's Finale from his string quartet no. 17 (16), opus 135, where following the title «Der schwer gefaßte Entschluß» (The Difficult Decision) there is a musical line without any designation of in-

Kirillina, Larisa. Cit. work, p. 107. 
strument, but with the following words written under the notes: «Muss es sein? Es muss sein! Es muss sein!» («Must is be? It must be! It must be!»). Rhetorical musical figures do not stand out conspicuously from the musical context; they are elements of the immediate musical expression itself. Such are the discernable figures present in Mozart's Requiem: «saltus duriusculus» in Kyrie eleison, «suspiratio» in Lacrimosa, and «exclamatio» in Rex tremende. In the «Grave» movement from Beethoven's «Pathetique» Sonata we can discern the "exclamatio», «suspiratio», coloring effects, «passus duriusculus» and «saltus duriusculus».

The paradigm of «Absolute Music,» established in the works of the Viennese Classicists, comes close to bringing to an absolute the definition of the primary aspect of musical content: the emotional category. But even here, music in general does not ignore the other two complimentary categories: depiction and symbolism.

The musical paradigm in the art of Romanticism in the $19^{\text {th }}$ century distinguishes itself by a further the elevation of the emotional category in music, which was the greatest throughout the entire time span since the Early Modern Period (most notably in the second half of the century), but retaining the secondary role of the side category of symbolism.

In the sphere of emotion the adopted terminology of that time no longer included «affects» re, but instead presented such concepts as «feeling», «experiencing emotion» and «mood». The role of emotion in Romantic music was such that, along with it, the emotionalistic concept of musical art was established as being the «language of feeling». «Music is the stenography of feeling» as Leo Tolstoy concluded. The novelty of musical feeling was essentially the result of the discovery of the human being's inner world. Very revealing is the testimony of Prince Vladimir Odoyevsky in regard to this': "In the beginning of the $19^{\text {th }}$ century Schelling was like Christopher Columbus in the $15^{\text {th }}$ century: he revealed to his contemporaries a world unknown to them, of which only some legends existed... their Souls!... Everyone rushed into this wonderful and luxurious land: some were stimulated by the example of the brave sea-explorer, others by striving for knowledge, curiosity or profit. Some people acquired many treasures there, while others took along monkeys and parrots, but many were drowned ${ }^{2} \gg$. The formation of the Russian school of classical music in the $19^{\text {th }}$ century played a significant role in the process of elevating the role of emotion in $19^{\text {th }}$ century music, since the conception of music as an essential force of the soul was traditionally

Vladimir Feodorovich Odoyevsky 1803-1869: philosopher, music critic and writer.

Odoyevsky, Vladimir F. Russkiye nochi [Russian Nights]. — Works in 2 volumes. - Vol. 1 -Moscow, 1981 - p.41. inherent in Russian culture. It is not perchance that this emotionalistic concept of music acquired its optimal manifestation in the music of Tchaikovsky.

The content of musical emotion in $19^{\text {th }}$ century music revealed the following tendencies: Love, Death, and the two in combination. This is especially apparent in the fact of the appearance at that time of two compositions which have acquired a symbolically ritualistic significance for that time and for future times: Mendelssohn's «Wedding March» and Chopin's «Funeral March.»

The fact that the Romantic era in particular became the time period of the flourishing of lyrical love poetry as an embodied musical experience (unlike the love chansons and madrigals of the Renaissance, for example) is also clearly manifested by the subjects and the titles of many musical compositions. Examples include: Schumann's song cycles, «Dichterliebe» («The Poet's Love») and «Frauenliebe und Leben» («A Woman's Love and Life»), as well as separate songs from various other song cycles: «Die Minnesänger» («The Singer of Love»), «Rastlose Liebe» («Restless Love»), opus 33, Nos. 2\&5, «Liebesgarten» («Love's Garden») and "Liebhabers Ständchen» ("Lover's Serenade»), opus 34, Nos. 1\&2, «Liebeslied» («Love Song»), opus 51 No.5, «Herzeleid» («Heartache»), opus 107 No.1, «Es leuchtet meines Liebe» («My Love Gleams») opus 127 No.3, «Aveu» («Confession»), from «Carnaval,» songs by Grieg: «Du fatter ei Bølgernes evige Gang» («The Heart of a Poet»), «Dig elsker jeg» («I Love You, Dear»), opus 5 Nos. 2\&3 (both songs have also been transcribed by the composer for solo piano), «Kjærlighed» («Love»), opus 15 No.2, «Dulgt kjærlighed» («Hidden Love»), opus 39 No.2, «Erotik», from the «Lyric Pieces», opus 43, vol. 3, No.5 and «Elsk» («Love»), opus 67, vol.2, No.5, as well as songs by Liszt,: «O liebe solang du lieben» («O Love as Long as You Can»): song no.3, S.541 from his cycle «Liebesträume» («Dreams of Love») and «Es muss ein wunderbares sein» (It Must be a Wonderful Thing»), S.314. Love also became the main subject in many operas: «L'elisir d'amore» by Donizetti, «La Traviata» and «Othello» by Verdi, «Eugene Onegin», «The Enchantress», and «The Maid of Orleans» by Tchaikovsky, «The Demon» by Rubinstein, etc. It is noteworthy that the opera «Eugene Onegin» contains four declarations of love. Entire genres were developed focusing on the content of lyrical love: the Russian «Romance» art song, the German Lied, the Nocturne, the Song without Words, the Album Leaf, etc.

The theme of lyricism of love became conspicuous in all its tints: that of chaste love in Igor's Aria "You are my darling» from Borodin's «Prince Igor,» reticent expression of love in «Aveu» from Schumann's «Carnaval,» impassioned declaration of love Lensky's Aria: «I Love You» from in Tchaikovsky's opera «Eugene 
Onegin,» declaration of love with tears and reproaches in Lyubasha's aria: "Yet it is I, Alone, who Loves You» from Rimsky-Korsakov's «The Tsar's Bride,» love with a tinge of pleasure, as in the love theme from Verdi's "Othello,» longing love, as in the theme of longing love from Wagner's "Tristan and Isolde,» the theme of agitated, impulsive love, as in Schumann's «Widmung» (Dedication) from «Myrthen,» opus 25 No.1, etc.

The theme of death was developed extensively by the Romanticists; this was primarily due to the sharp change in world perception among artists of that time. The utopias from the Age of Enlightenment had been shattered, religious faith was greatly weakened, and there was a widespread tendency of feeling abandoned and lonesome in a huge and frightening world. An immense position in art was taken up by depiction of the devil and other negative imagery; in music emotions of grotesquerie became prominent (as described by Victor Hugo and developed in his works). Around that time Jean Paul ${ }^{1}$ developed infernal jest as one category of humor in his work «Vorschule der Aesthetik» («Introduction to Aesthetics», 1804). Half a century later, Johann Karl Friedrich Rosenkranz ${ }^{2}$ wrote his treatise, «Aesthetik des Hässlichen» (The Aesthetics of Ugliness, 1853).

The significance of the theme of death in Romantic music and art is tellingly described in the titles of musical pieces: Schubert's lieder «An den Tod» («To Death»), «Der Tod und das Mädchen» («Death and the Maiden»), Wagner's opera "Götterdämmerung,» Brahms's «O Tod, wie bitter bist du» («O Death, how Bitter You Are» the third of the "Four Serious Songs», opus 121), Mussorgsky's «Songs and Dances of Death,» Liszt's «Totentanz» («Dance of the Dead), «Czardas Macabre», "La lugubre gondola» («The Lugubrious Gondola») and «Funerailles» and Richard Strauss's symphonic poem «Death and Transfiguration». Chopin's Prelude in F-minor contains a hidden program of «suicide», which would have been absolutely impossible to carry out from the position of the musical aesthetics of the preceding eras. The genre of the funeral march as part of instrumental compositions was firmly established. The poetic genre with tragic ending depicting catastrophe became the prototype of many musical compositions - namely, the ballad. It is exemplified by such musical works as Schubert's «Der Erlkönig» («The Forest King») and Chopin's Ballades for piano. Various vocal cycles and largescale instrumental works with tragic endings were composed, such as Schubert's «Winterreise» («The

Jean Paul 1763-1825: born as Johann Paul Friedrich Richter, German Romantic writer.

Johann Karl Friedrich Rosenkranz 1805-1879: German philosopher and pedagogue.
Winter Journey») and Tchaikovsky's $6^{\text {th }}$ Symphony. The diabolical element, mockery, and grotesquerie found their presence in opera (exemplified by Arrigo Boito's "Mefistofele» and Gounod's «Faust»), symphonic music (Berlioz's «Symphonie Fantastique» and Mussorgsky's «Night on a Bald Mountain») and works for piano (Schumann's «Humoresque,» Liszt's three Mephisto Waltzes and Mephisto Polka and Scriabin's «Satanic Poem»).

Correspondingly diverse is the palette of emotions embodying the themes of tragedy and death from the "Der Leiermann» («The Hurdy-Gurdy,» the last song from Schubert's «Winterreise») to the storms of passion in Chopin's Ballades.

Particularly striking is the special work of the Romantic composers on establishing «mixed emotions» in music, going as far as even to unify polar opposites in a single entity - love and death. Of course, mixing different tints of feelings and affects had been done in prior times, and even conceived of theoretically. However, in the $19^{\text {th }}$ century they achieved their highest point of paradoxical polarity, giving rise to outstanding musical discoveries. The «mixture of emotions» was placed in the same high position as «mixture of forms» and "mixture of genres». The composer who learned to convey «mixed emotions» consciously in theory and in practice was Robert Schumann. He pondered about this and described it in his letters to Clara Wieck: «lt was a mixture of feeling anger and bliss,» «l suffer greatly, but it is beautiful; these are the tears upon flowers," "this is wonderful and horrible - all at once," «there is no such thing as lovely melancholy» (1838-39) ${ }^{3}$. In Schumann's music the "mixture of feelings» was realized the most in the following songs from «Dichterliebe» (1840): «Im wunderschönen Monat Mai» («In the Beautiful Month of May»), «Und wüßten's die Blumen, die kleinen» («If the Little Flowers only Knew»), «Ein Jüngling liebt ein Mädchen» («A Youth Loved a Maiden») and, in a specially striking manner, «Ich grolle nicht» («I do not Chide You»). Examples of works by other composers include Tchaikovsky's song «l bol'no i sladko» («lt is both Painful and Sweet») and Liszt's song «Freudvoll und Leidvoll» (Joyful and Sorrowful). A conspicuous musical monument to the unresolved polarity of «love-death» was set up by Wagner in his opera «Tristan and Isolde». The famous «Tristan chord," with its ambiguity of harmonic function, has been generated by the story of the transformation of a goblet with poison into a goblet with love potion. This ambivalence of emotional meaning pervades throughout the entire opera, as well as in

These given materials are presented in the diploma thesis by Evgeny Metrin, written under my supervision at the Moscow Conservatory, 2003. 
its particular scenes, such as «So starben wir» in Act 2 , with its solemn funeral-like character of the music. The poignant lyricism in the scene of the Snow Maiden's melting, "l Love and I Melt», from RimskyKorsakov's opera «Snegurochka» («The Snow Maiden») was achieved by the composer also as part of his artistic manifestation of the irreconcilable polarities of love and death. It was here that a chord of extra intensity, containing a major seventh, was created.

The emotional processes in $19^{\text {th }}$ century music are characterized by a certain amount of particular features: considerably long durations of the portrayal of each emotion, dramaturgical - rather than syntactical - contrast between alternating emotions, the wave principle of the development of human emotions and the importance of climax points, both the dynamic and the subdued types. For example, in the first movements of Tchaikovsky's Fourth, Fifth and Sixth Symphonies the duration of expression of each emotion results in the extended forms of the primary and secondary theme groups and the dramaturgical contrast between them, the immense waves of emotional expression within the pairings of the principal/ transitional and the secondary/closing theme groups, as well as the successive portions of the development sections. An established hierarchy of climactic points is present in the aforementioned pairings of theme groups, in the complete expositions, the waves within the development sections, the coda and in the entire sonata form. The lyrically refined effect of subdued climactic points adds beauty to many musical works, such as those by Chopin, Schumann and Rachmaninoff.

In regard to depiction in music, the Romanticist composers expressed theoretical theses which were quite different from those of the Classicists. In Schumann's opinion a musical composition would captivate more if it contained elements from the other art forms - those visible to the eye or contained in a verbal text. Berlioz developed an entire «theory of imitation» (as described in his essay, "De l'imitation musicale»). According to him, music which appeals to the auditory sense alone may «arouse in us by means of sound the notion of several passions of the heart, and to awaken solely through the sense of hearing, the impressions that human beings experience only through other senses» ${ }^{1}$. He defined four basic stipulations «for direct or physical imitation:»

1. It must be «a means and not an end»,

2. It must be applied «only to such objects that deserve the listeners' attention»,

Berlioz, Hector, «De I'Imitation musicale,» translation reprinted in Hector Berlioz: Fantastic Symphony, Norton Critical Scores, Edward T. Cone (ed.). New York: W.W. Norton \& Company Inc., 1971, p.43.
3. It «must not substitute musical art for mere copying of natural sounds»,

4. «Physical imitation must never take the place of imitation of human sensibility (i.e. expression) ${ }^{2}$.»

The composer realized his manifesto artistically in his most important compositions — «Symphonie Fantastique», and «Harold en Italie.»

The trend of musical depiction was widely developed in the $19^{\text {th }}$ century Russian school in accordance with the aesthetics of realism, which has always been inherent in Russian art. The extensive visible world of realism was realized artistically in the music of the «Mighty Handful:» Borodin, Cui, Mussorgsky, Rimsky-Korsakov and, subsequently, such composers as Lyadov and Rachmaninoff (the latter in his orchestral music, operas and songs). Depiction became an indispensable element in the music of the Norwegian composer, Grieg. In Germany Richard Strauss was also deeply enthralled by this method.

The category of symbolism in the musical content of the $19^{\text {th }}$ century becomes secondary in importance, as compared to the aspects of emotion and objectdepiction, but, nevertheless, it is present and takes on a number of different forms. One of these is the use of programmatic titles to musical pieces. According to Schumann, «the successfully chosen title enhances the impact of the music». In Berlioz» opinion, «in order for the prototype of these images to be accurately recognized, the listener must be forewarned with some kind of hint of the composer's intention ${ }^{3}$.» An extensive amount of individual titles appeared together with the instrumental cycles by Schumann («Carnaval», «Fantasiestücke», «Kinderszenen», «Album für die Jugend», «Waldszenen», «Albumblätter»), Tchaikovsky («Children's Album», «The Seasons»), Grieg («Lyric Pieces»), the symphonic poems of Franz Liszt and Richard Strauss, and the symphonic tone-pictures of Liadov, etc.

A «light» type of symbol could be perceived in the reflection of a particular genre in another type of genre. In the $19^{\text {th }}$ century, a well-defined method of «multi-genrism» developed, analogous to the $20^{\text {th }}$ century method of «polystylistics» ${ }^{4}$. The association between music from any given genre with a different type of genre beside it concretizes the musical image by means of the semantics of the reflected genre. For example, in his Violin Concerto no.8, Louis Spohr put the following subtitle, «In the Form of an

\footnotetext{
Berlioz, Hector, Izbrannye statyi [Selected Articles]. Moscow, 1956, pp. 88-89.

Berlioz, Hector. Izbrannye statyi [Selected Articles]. Moscow, 1956, p. 89.

This issue was the main subject of the Candidate of Arts dissertation of T. Samvelyan "Multi-genres in Chopin's Piano Compositions» written at the Moscow State Conservatory under my supervision - Moscow, 2000.
} 
Operatic Scene,» directing the listener's associations towards the genres of the opera arias, the orchestral ritornello, the recitative, etc. For the most part, composers were able to manage without subtitles, relying on the listener's unmistakable aural recognition of the associations conceived by them, as occurs, for example, in Chopin's Preludes in C-minor and A-major. This method of multi-genrism with its non-verbal associations achieved its fullest completion in the music of Chopin, and it was drawn upon extensively by Brahms and Rachmaninoff.

An important form of symbolism in the $19^{\text {th }}$ century was the operatic Leitthema («leading theme») and leitmotif («leading motive»), which historically supplanted the use of rhetorical musical figures. These were essentially concrete musical «gestures» endowed with fixed, well-defined semantic meanings (especially prominent in the operas of Wagner and Rimsky-Korsakov). Rhetorical musical figures remained merely as rudiments, used in individual cases - by such composers as Chopin, Schumann, and Glinka.

In the Romantic era there was minimal usage of symbol-quotations; one composition in which they were present was Tchaikovsky's 1812 Overture, which incorporated a number hymns, national anthems and patriotic songs, such as "God Preserve Thy People», "Le Marseillaise», "Near the Gates, the Gates» and «God, Save the Tsar!» A rare but exceptionally significant occurrence of symbolism was the «lettered theme» A-S-C-H (which is German for A, E-flat, C, B-natural) in Schumann's "Carnaval» (subtitled «Little Scenes Written on Four Notes»). Asch is the name of a Czech town where Schumann's beloved girl lived, and the same letters also spell part of the monogram of Schumann's name; A-sch.

The music of the $20^{\text {th }}$ century established its own paradigm, which greatly differed from the three previously discussed ones. The category of emotion reached its extremes of expression, having lost its full spectrum of diversity of imagery, with a sharp decline in object representation, while the aspect of symbolism reached heights never before attained in the entire history of musical culture.

Within the sphere of emotion, the notion of «feeling» was gone, even the idea of «emotion» was put into doubt - all that remained was just «character.» The emotionalist concept of music was shattered. There was harsh reaction against the lyricism of love as something which had exhausted itself entirely in the Romantic Era. Serious classical music bore great losses in the sphere of expression of «basic human feelings» - joy, energy, cheerfulness, sentimental sadness, etc. The vacuum which was formed as the result of this was filled by swiftly developing subcultures: jazz, cultivating the pleasures of life, rock music with its highly wound-up affirmations of life, pop song with its lyrical sentimentality, etc. Only in a few select musical compositions does the theme of love appear in its utmost capacity, as in Poulenc's opera «La voix humaine», certain episodes in Prokofiev's operas «Betrothal in a Monastery» and "War and Peace» and, towards the end of the $20^{\text {th }}$ century, Rodion Shchedrin's opera «Lolita» and Violin Concerto, subtitled «Concerto Cantabile». For $20^{\text {th }}$ century music a particularly representative occurrence is presented when sometimes a gentle, lyrical theme is presented in the guise of deceitfulness. This occurs in the sweet «love duet» between the viola and double-bass along with soft, nocturne-like arpeggios from the piano in Alfred Schnittke's Viola Concerto, which the composer himself called «sweet filth». The most radical directions of the $20^{\text {th }}$ century were focused on two extremes: either emotional hypertrophy or complete lack of emotion. The first is typical for musical Expressionism (in the music of Schoenberg and Berg), but also for the music of Shostakovich, Schnittke, Penderecki, and Boris Tishchenko ${ }^{1}$, while the second is characterized by modernism (Hindemith, Stravinsky) and especially by post-war avant-gardism (Boulez, Nono, Stockhausen). There are also examples containing different interim ranges between these two polarities.

The triumph of emotionalism in Expressionism reached a point of naturalistic expression with the inclusion of human outcries. Examples of this are Maria's scream as she is being killed by Wozzeck, the outcry of Lulu being killed by Jack the Ripper (both from Alban Berg's operas), as well as the screams of the maidens being sacrificed in Schoenberg's opera «Moses und Aron.» Similar emotional outcries appear into several other music scores: the cries of the crowds from Penderecki's «St. Luke's Passion,» the outcries from the chorus in the climax section from Arvo Pärt's «Credo», Rodion Schedrin's «The Execution of Pugachev», as well as screams and sarcastic laughter of the soloist in Gubaidulina's «Rubaijat.» In his Second Sonata for Violin and Piano Schnittke implemented the idea of «unlimited expression». Exceptional in its effect is the climax, with its frenzied «bangs» on a G-minor chord in the piano part carried out 114 times, with a fff dynamic marking. Another form of expression, connected with the upheavals in the domain of musical rhythm, was present in Stravinsky's early ballets, in a number of Bartok's works («Allegro barbaro» and «Sonata for two pianos and percussion»), and Prokofiev («Scythian Suite», «Le Pas d'Acier» and Toccata for piano). A peculiar type of «instant expression» was introduced by Webern in

Boris Tishchenko, 1939-2010; Russian composer and pianist. 
his aphoristic works, providing separate individual sounds with attributes of quivering, trembling, exclamations, fading, thawing, etc. His discoveries within the realm of emotional expression were intensely developed by composers in the second of half of the century - particularly by Gubaidulina, who introduced into her music such moments of expression as the moaning of the cello, naturalistic sighs of the bayan, the laughter of the bassoon, "the breath of The Holy Spirit» in stringed instruments.

The extremes of non-emotion are found in the structural works of Boulez, such as «Structures 1» for two pianos and «Le marteau sans maître.»

Emotional processes also acquired peculiar characters in the $20^{\text {th }}$ century. On the micro-level, a distinct sign of modernity was the implementation of the phasing of sound: dynamic intensification or abatement of a single continuous line. Examples of this include the Six Pieces for Orchestra, opus 6 by Webern, Berg's «Lyric Suite» and Edison Denisov's «Three Short Pieces for Cello» and «Romantic Music.» On the macro-level, waves of emotion enveloped the span of the overall form in certain musical compositions. For example, the slow movement of Schnittke's First Symphony contains a wave of intensification of sound lasting 120 measures, followed by a reverse process of abatement of sound lasting 60 measures. In works containing parallel dramaturgy, there emerged the effect of subito-contrasts, in moments of shifting from one channel of effect onto another: for example, switching from a meditative emotional mood to an active one and vice-versa, as in the symphonies of Giya Kancheli, for example 1 . There appeared musical forms with processes containing either only crescendos or only diminuendos. Examples include «crescendo» forms in «The Eclipse» from Boris Tishchenko's «Yaroslavna,» and the first movement of the Second Symphony by Avet Terterian ${ }^{2}$ and the «diminuendo» form in the exposition of «Regard des prophètes, des bergers et des Mages' from Messiaen's "Vingt regards sur l'enfant-Jésus.». Certain monoplane static forms on a single level of emotional dynamics became distinguished as well, such as «Piece No.1 for Orchestra» by Zygmunt Krause ${ }^{3}$ and «Homeophony» by Leonid Grabovsky ${ }^{4}$. Upon extremely long durations, certain static forms reached psychedelic emotional effects, suchas, for instance, Stockhausen's «Stimmung» for 6 singers (lasting $70 \mathrm{~min}$.), «Agnus Dei» for four instruments (lasting $120 \mathrm{~min}$ ) and «Nika» in 72 fragments for 17 performers (lasting $140 \mathrm{~min}$.), both by Alexander Knaifel ${ }^{5}$.

\footnotetext{
As noted by Elena Mikhalchenkova.

Avet Terterian, 1929-1994; Armenian composer

Zygmunt Krauze, born 1938; Polish composer

Leonid Grabovsky, born 1935; Ukrainian composer

Alexander Knaifel, born in 1943; Russian composer
}

The significance of object-depiction became noticeably reduced. It is reasonable to classify Debussy's style, abundant with object-depiction, as presenting a conclusion to the musical style of the $19^{\text {th }}$ century. Prokofiev's keen interest in object-depiction bears witness to the direct continuation in his music of this side category inherent in the Russian national musical tradition. This can be seen in such examples as «Juliet, the Maiden», «Father Lorenzo», and «The Fight between Tybalt and Mercutio» from the ballet «Romeo in Juliet,» as well as "Morning», "Grasshoppers' Parade» and «A Little Fairy-Tale» from «Music for Children.» Musical depiction in the $20^{\text {th }}$ century took refuge in music for children, which had been developed more broadly in that century than in any previous one. Examples include Prokofiev's «Peter and The Wolf,» Bartok's «Mikrokosmos,» Shchedrin's «Notebook for Young People,» «Children's Toys» by Gubaidulina, «Children's Album» (98 pieces), «Pieces for Children» (99 pieces) and «Lyoka's Notebook» (59 pieces) by Roman Ledenev 6 , etc. Another notable feature in $20^{\text {th }}$ century music and art was objectless depiction: the spatiality in «Notebook for Young People» by Shchedrin, the juxtaposition of various points («here» and «there») in the works of Gubaidulina, «the secret was opened to him» in Schnittke's «Faust.»

Symbolism in the $20^{\text {th }}$ century reached a peak of universality that it never possessed before. This occurrence was the result of the intellectualism acquired by serious, classical music in the previous $\left(20^{\text {th }}\right)$ century. It is also connected to the aforementioned loss of emotionality that happened to this form of art. The various types of symbolism can be counted as no less than ten of both the verbal and the non-verbal varieties. This includes the symbolism of genres, styles, individual titles, written down programs, lettered monograms, quotations, numbers, gestures, theatrical movements, as well as the total form of symbolism.

The symbolism of genres essentially presents that «mild» form of associativity which came out of the tradition of multi-genrism from the $19^{\text {th }}$ century and played a visible role in the works of various composers, of which mention must be at least made of Shostakovich. Examples of this can be found in his 24 Preludes opus 34, 24 Preludes and Fugues opus 87, the Symphony No.4, and many other pieces. The symbolism of styles formed the foundation for the widespread trend of polystylism, which was a special favorite of the Russian composers Stravinsky and Schnittke. Individual titles of works form a distinct feature of $20^{\text {th }}$ century music, having been broadly implemented and sometimes serving the purpose of presenting a concentration on an idea, as in the case of Gubaidulina in her sympho-

Roman Ledenyov, born 1930; Russian composer 
nies, «Stimmen... Verstummen» (Voice... Silence) and «Figures of Time,» as well as her other pieces, such as «In Croce» (The Cross), «Lightness and Darkness», "Dancer on a tightrope», etc. However, it is notable that many of the titles of compositions from the $20^{\text {th }}$ century very often gravitate towards abstract and technical terms. Examples include: Xenakis' works: «Terretektorh», «Pithoprakta», «Syrmos», «Nomos gamma», "Diamorphoses», and "Amorsima-Morsima," Boulez's «Figures, doubles, prismes», «Éclat», «Pli selon pli» and "Repons,» Stockhausen's «Momente», «Plus Minus» and «Telemusik,» Berio's "Circles» and «Labyrinths,» as well as Penderecki's «Emanations», «Anaklasis», «Polymorphia» and «Fonogrammi». Nonabstract titles often reveal negative imagery: "Songs and Dances of Death,» the subtitle of Shostakovich's Symphony No.14, "Auschwitz» by Ilja Zeljenka ${ }^{1}$ and «Psychodrama» by Tadeusz Baird². The occasional use of text programs by various composers, most notably, Shchedrin is connected in his case with the conscious «Russianness» of his subject matter and the aesthetics of Russian realism he incorporates. This can be seen in his Fifth Concerto for Orchestra, titled «Four Russian Songs», and his Third Symphony entitled «Images of Russian Fairy Tales». Symbolism in the form of musical cryptograms (or monograms) became widely spread in unprecedented degrees. Examples of this can be found in Berg's cryptogram of «Gropius» in the Violin Concerto, «Hanna Fuchs» in the Lyric Suite, «Arnold Schoenberg, Anton Webern and Alban Berg» in the Chamber Concerto. Schnittke used in cryptographic forms 33 names of composers in three of his symphonies and Igor Stravinsky's full name in "Canon in the Memory of Stravinsky.» The monogram of Bach (among others) was used by Arvo Pärt, Rudolf Wagner-Régeny ${ }^{3}$, Pendercki, Georg Katzer ${ }^{4}$, and many others. The cryptogram of DSCH was used by Kara Garayev ${ }^{5}$, Myroslav Skoryk ${ }^{6}$, Nicholas Slonimsky ${ }^{7}$, Tishchenko, Andrei Eshpai ${ }^{8}$, Edison Denisov ${ }^{9}$, Günter Kochan ${ }^{10}$, Jean-Yves Daniel-Lesur ${ }^{11}$,Ernst Hermann Meyer ${ }^{12}$, David Matthews ${ }^{13}$,

\footnotetext{
Ilja Zeljenka, 1932-2007; Czech-Slovak composer

Tadeusz Baird, 1928-1981; Polish Composer

RudolfWagner-Regeny, 1903-1969; Hungarian-German composer

Georg, Katzer, born 1935; German composer

Kara Karayev, 1918-1982; Azerbaijanian composer

Myroslav Skoryk, born 1938; Ukrainian composer

Nicholas Slonimsky, 1894-1995; Russian-born American composer

Andrei Eshpai, born 1925; Russian composer

Edison Denisov, 1929-1996; Russian composer

Günter Kochan, 1930-2009; German composer

Jean-Yves Daniel-Lesur, 1908-2002; French composer

Ernst Hermann Meyer, 1905-1988; German composer and musicologist

13 David Matthews, born, 1943; English composer
}

Carlos Palacio ${ }^{14}$, and Ronald Stevenson ${ }^{15}$. The cryptogram of Denisov, being EDS or ED, was used by Denisov, Gubaidulina, Slonimsky, Ledenev, and Dmitri Smirnov ${ }^{16}$. The symbolism of musical quotations enriched the semantics in the works by Stravinsky, Shostakovich, Berg, Poulenc, Berio, Schnittke, Matthews, Shchedrin, Faraj Karayev ${ }^{17}$, Viktor Ekimovsky ${ }^{18}$, Vladimir Tarnopolsky ${ }^{19}$, Alexander Vustin ${ }^{20}$ and many others.

The revival of the symbolism of numbers, at least in part, formed an arch leading back to the Baroque, Renaissance, and the Middle Ages. For example, in Schnittke's «Biography» (written by the composer for his $48^{\text {th }}$ birthday), numbers are used to demonstrate acceleration in the course of human life: the grouping of measures using the numbers $12,9,8$, and 6 , and using the following numbers for tempo designation, 60,80 , 90,120 . The general duration is set for 8 minutes and 40 seconds. Gestures either imitating or substituting musical sounds have also been incorporated by the composers of this time period. Examples include Schnittke's Third Violin Concerto, with the solo violin not producing any sounds, but incorporating gestures, Gubaidulina's cadenza for solo conductor (with hand gestures) from the symphony "Stimmen... Verstummen» and the soundless «Night Song of The Fish» from «Galgenlieder» (Songs of The Gallows). Striking examples of instrumental theatre could be found in Mauricio Kagel's works «Sonant» and «Under the Stream» and in Victor Ekimovsky's «Balletto.» The idea of total symbolism was brought out by John Cage in his famous work «4'33» «. The pure symbol pushed aside the most important sign in music: the icon. However, the various lacunae of certain expressions of emotion were compensated by the incredible expansion of symbolism throughout, albeit this compensation has not been entirely harmless; this situation brings in the danger for classical, academic culture of becoming a subculture.

Through the use of contrasting comparisons, we have viewed a demonstration of four major periods of music from the Early Modern Period to the New Age. The problems of their most significantly meaningful characteristics cannot be resolved by means of theory of musical composition, regardless of how advanced or perfected it may be. Only a musically-substantive approach may permit them to be investigated analytically and synthetically.

\footnotetext{
4 Carlos Palacio, 1911-1997; Spanish composer

Ronald Stevenson, born 1928, British composer

6 Dmitri Smirnov, born 1948; Russian composer

Faraj Karayev, Born 1943; Aizerbaijanian and Russian composer, son of Kara Karayev; 1918-1982

8 Victor Ekimovsky, born 1947; Russian composer

9 Vladimir Tarnopolsky, born 1955; Russian composer

20 Alexander Vustin, born 1943; Russian composer
} 


\section{REFERENCES (TRANSLITERATED)}

1. Berlioz, H. O podrazhanii v muzyke [On Imitation in Music] //Berlioz H. Izbrannye statyi [Selected Articles]. Moscow, 1956.

2. Glinka, M. I. Literaturnye proizvedeinya i perepiska [Literary Works and Correspondence]. Vol.1, Moscow,1973.

3. Diletsky, N. Ideya grammatiki musikiyskoy. [The Concept of Musical Grammar] Publication, research and commentaries by Vladimir Protopopov. Moscow, 1979.

4. Kirillina, L. Klassicheskiy stil v muzyke XVIII - nachala XIX vekov [The Classical Style in $18^{\text {th }}$ and Early $19^{\text {th }}$ Century Music]. Moscow,1996.

5. Couperin, F. Iskusstvo igry na klavesine [L'Art de Toucher le Clavecin]. Moscow,1973.

6. Metrin, E. «Smeshannye chuvstva» Roberta Shumana [«The Mixed Feelings» of Robert Schumann // Muzykal'noye soderzhaniye: nauka i pedagogika [Musical Content: Scholarship and Pedagogy]. Moscow — Ufa, 2002.

7. Muzykal'naya estetika Zapadnoy Yevropy XVII-XVIII vekov [The Musical Aesthetics of Western Europe in the $17^{\text {th }}$ and $18^{\text {th }}$ Centuries]. Moscow,1971.

8. Nosina V. B. Simvolika muzyki I.S. Baha [The Symbolism of J.S. Bach's Music]. Moscow, 2004.

9. Odoyevsky V.F. Sochineniya v dvukh tomakh [Works in 2 Volumes]. Vol.1. Moscow,1981.

10. Samvelyan T.E. Polizhanrovost» v fortepiannykh proizvedeniyakh Shopena [The Poly-Genre Features in Piano Compositions by Chopin]. Dissertation for the degree of Candidate of Arts. Moscow, 2000.

11. Tolstoy, L. N. Polnoye sobraniye sochineniy v 22 tomakh [Complete Works in 22 Volumes]. Vol. 22. Diaries from 1895-1910. Moscow,1985.

12. Kholopova, V. Kak nazvat» 20 vek v muzyke? [How to Label the $20^{\text {th }}$ Century in Music] // Ekaterina Aleksandrovna Ruchyevskaya. K 90-letiyu so dnya rozhdeniya [Ekaterina Aleksandrovna Ruchyevskaya. Towards the $90^{\text {th }}$ Anniversary of Her Birth. St. Petersburg, 2013.

13. Kholopova, V. N. Muzykal'nye emotsii [Musical Emotions]. Moscow, 2010, 2012.

14. Kholopova, V.N. Formy muzykal'nykh proizvedeniy [Form of Musical Compositions]. St. Petersburg, 2013.

15. Kircher A. Musurgia universalis. Roma, 1650.

16. Peirce C.S. Collected Papers. Ed. by C. Hartshorne and P. Weiss, Arthur W. Burks. Vol.1-8. Cambridge -Mass, The Belknap Press of Harvard University Press 1965-1967.

17. Walther J.G. Musicalisches Lexicon, oder musicalische Bibliothec. Leipzig, 1732. 
